\title{
Pengaruh Duty Cycle terhadap Perpindahan Energi pada Motor BLDC (Brushless Direct Current) saat Pengereman Regeneratif Berbasis dsPIC30f4012
}

\author{
${ }^{1}$ Helmi Aulia Rahman, ${ }^{2}$ Slamet Riyadi \\ Program Studi Teknik Elektro, Fakultas Teknik, Universitas Katolik Soegijapranata, Semarang \\ 1helmiaulia007@gmail.com, 2sriyadi7167@gmail.com
}

\begin{abstract}
Abstrak
Beberapa dekade terakhir, dunia industri transportasi elektrik mengalami perkembangan yang cukup pesat. Hal ini dapat ditinjau dengan banyaknya transportasi elektrik yang menggunakan motor listrik modern sebagai penggerak elektrik. Salah satu jenis motor listrik modern sebagai penggerak elektrik adalah motor BLDC (Brushless Direct Current). Motor BLDC memiliki beberapa keunggulan seperti konstruksi yang sederhana, mudah mengatur kecepatannya serta memiliki torka yang besar, dan memiliki efisiensi tinggi. Motor BLDC memiliki kelemahan, diantaranya sistem kontrolnya yang rumit. Akan tetapi memiliki kelebihan khusus yang mampu melakukan pengereman secara regeneratif. Pengereman regeneratif dapat meningkatkan efisiensi karena pada saat terjadi pengereman, energinya bisa disimpan ke batere. Penelitian ini mengusulkan metode sederhana untuk melakukan efisiensi energi saat motor melakukan pengereman regeneratif, dengan mengatur besar kecilnya duty cycle untuk mengetahui pengaruh perpindahan energi pada motor BLDC ke sumber batere. Hal ini dapat dilihat melalui arus charging dan kecepatan motor BLDC.
\end{abstract}

Kata Kunci: motor BLDC (Brushless DC), duty cycle, perubahan energi, pengereman regeneratif, inverter tiga fasa.

\section{Pendahuluan}

Perkembangan industri transportasi elektrik saat ini banyak yang menggunakan penggerak motor listrik modern. Salah satu jenis motor listrik modern yang digunakan adalah motor BLDC. Beberapa keunggulan motor BLDC diantaranya mudah untuk mengatur kecepatannya, dan lebih handal sebagai penggerak pada kendaraan listrik [1][2]. Selain digunakan sebagai penggerak pada kendaraan listrik, motor listrik modern juga memiliki kelemahan yaitu kontrolnya yang rumit karena menggunakan kontrol digital. Pada umumnya pengereman penggerak elektrik menggunakan pengereman dinamik, dimana energi listrik dikonversi menjadi energi panas yang disimpan ke resistor [3]. Metode ini banyak diterapkan di industri transportasi elektrik yang membutuhkan sistem pengereman motor listrik.
Hal ini tidak efisien karena energi tidak dimanfaatkan kembali [4].

Motor BLDC dikontrol menggunakan mikrokontroller melalui pembacaan logika pada masukan sensor hall effect ditambah dengan rangakain daya inverter tiga fasa. Sumber tegangan inverter menimbulkan pergeseran fasa 120 derajat listrik yang berbentuk tegangan persegi atau trapezoidal [5][6]. Dengan memanfaatkan motor BLDC sebagai generator, maka inti rotor yang berupa magnet permanen akan muncul gaya gerak listrik sehingga terjadi perubahan energi kinetik pada motor menjadi energi listrik [7]. Dari hasil perubahan energi tersebut dapat mempengaruhi kecepatan motor, sehingga hal ini dapat disebut dengan pengereman regeneratif. Pengereman regeneratif merupakan proses pengereman yang memanfaatkan perpindahan energi dari motor penggerak disimpan kembali ke baterai, saat inersia motor memaksa motor menjadi mode generator [7][8].

Pada penelitian ini dilakukan kajian pengereman regeneratif dengan cara mengatur saklar - saklar pada IGBT (Insulated Gate Bipolar Transistor) di inverter. Kondisi ini akan memfungsikan IGBT di inverter sebagai boost konverter, sehingga tegangan keluarannya bisa lebih besar daripda tegangan batere.

\section{Metodologi Penelitian}

Motor BLDC merupakan motor listrik modern yang berjenis motor synchronous, yang memiliki keluaran kecepatan putaran motor sebanding dengan frekuensi yang masuk pada statornya [9].

Rangkaian ekuivalen masing-masing fasa pada stator motor BLDC ditunjukan pada Gambar 1 berikut ini. 
Seminar Nasional Instrumentasi, Kontrol dan Otomasi (SNIKO) 2018 Bandung, Indonesia, 10-11 Desember 2018

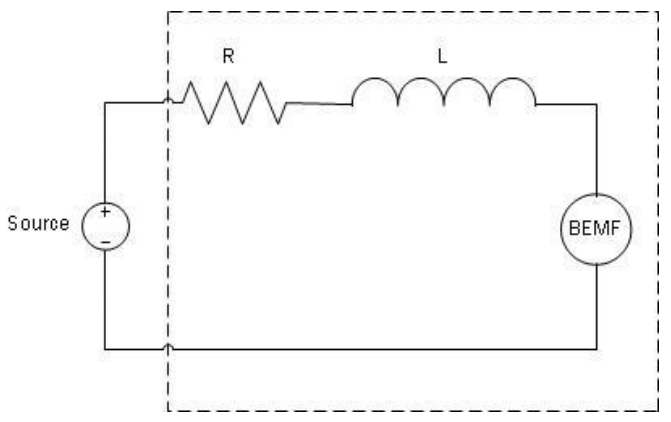

Gambar 1 rangkaian ekuivalen stator motor BLDC

Arus start awal akan sangat besar, karena dipengaruhi oleh resistansi dan induktansi yang sangat kecil serta BEMF $=0$. Motor akan berputar, lalu magnet permanen pada rotor bergerak melewati kumparan stator sehingga terjadi induksi, maka timbul beda potensial dalam kumparan tersebut. Hal ini dapat disebut dengan Back Electromotive Force atau BEMF. BEMF berbanding lurus dengan kecepatan motor yang ditentukan dari tegangan konstan motor [10]. Dari penjelasan tadi muncul persamaan :

$\mathrm{RPM}=\mathrm{Kv} \times$ Volt

$\mathrm{BEMF}=\mathrm{RPM} / \mathrm{Kv}$

Motor akan berputar dengan kecepatan sedemikian rupa sehingga EMF balik sedikit lebih kecil dari tegangan sumber. Arus yang dibutuhkan untuk menggerakan motor berbanding lurus dengan beban torsi motor. Sedangkan arus yang dibutuhkan ditentukan dengan torsi konstan motor [10].

Torque $=\mathrm{K}_{\mathrm{T}} \times$ Amps

Pada Gambar 2 ditampilkan rangkaian inverter tiga fasa yang dimanfaatkan sebagai pensaklaran dari sumber tegangan untuk pengisian batere.

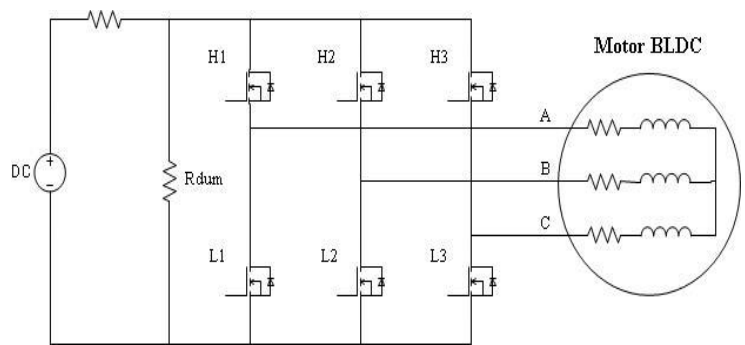

Gambar 2 rangkaian inverter tiga fasa

Pengendalian pada motor BLDC dengan cara pembacaan logika pada masukan sensor hall effect, kemudian hasil logika tersebut diproses dalam mikrokontroller untuk menghasilkan sinyal PWM (Pulse-width modulation). Hasil keluaran mikrokontroller yang berupa PWM akan diteruskan ke driver IGBT modul untuk disaklarkan pada frekuensi tinggi. Pada Gambar 3 adalah skema duty cycle

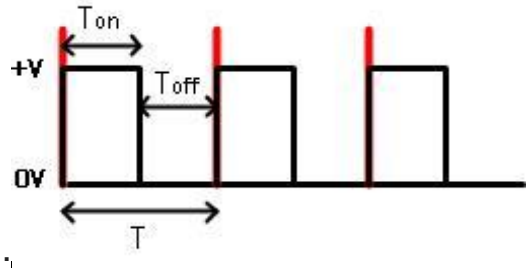

Gambar 3 skema duty cycle

Duty cycle merupakan persentasi durasi dari kondisi lebar pulsa ON dalam satu periode sinyal. Dari sinyal keluaran cukup mengatur besar kecilnya tegangan referensi. Besar kecilnya persentase duty cycle pada PWM dapat dihitung dengan cara :

$\mathrm{T}=\mathrm{Ton}+\mathrm{Toff}$

dutycycle $=\frac{\text { Ton }}{\mathrm{T}} \times 100 \%$

Prinsip pengereman regeneratif tergantung pada kontrol konverter boost pada rangkaian inverter. Mode pengereman regeneratif dilakukan untuk mencapai deselerasi atau daya pengurangan kecepatan pada motor BLDC. Hal ini dapat dilakukan dengan cara mengoperasikan saklar pada rangkaian inverter yang diprogram mikrokontroller dengan frekuensi yang tinggi.

\subsection{Desain Alat}

Di dalam penelitian ini inverter digunakan untuk mengendalikan motor BLDC pada saat motoring dan mengendalikan aliaran daya saat pengereman regeneratif, rangkaian ditunjukan pada Gambar 4.

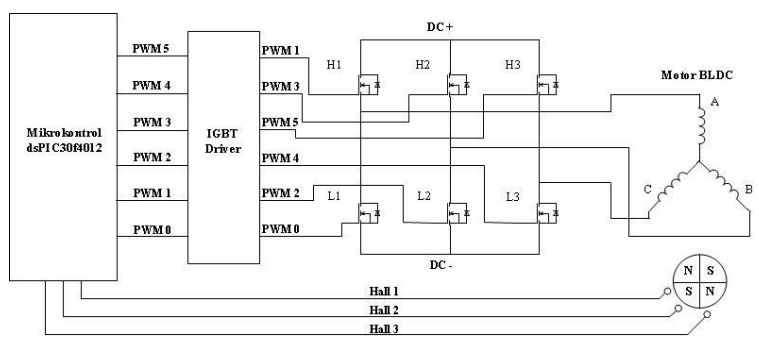

Gambar 4 kontrol blok diagram motor BLDC

Blok diagaram pada Gambar adalah bagian-bagian alat dan komponen yang digunakan, terdiri dari motor DC, motor BLDC, sensor hall effect, mikrokontroller dsPIC30f4012, driver TLP250, catu daya DC to DC konverter, IC buffer 74HC541, modul IGBT CPV364M4F, dan sumber daya DC atau baterai. Sistem kontrol merupakan bagian penting pada sistem ini yang akan menerima data dari sensor hall effect. Hasil keluaran sensor hall effect berupa pulsa gelombang kotak yang akan menjadi masukan pada mikrokontroller dsPIC30f4012. 
Untuk memahami proses pengereman regeneratif maka berikut ini dijabarkan mode - mode operasi, meliputi :

A. Mode Operasi 1 : $H_{1}$ dan $L_{2} O N$

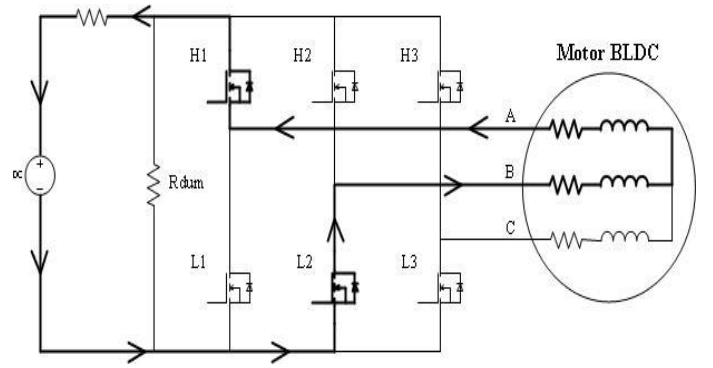

Gambar 5 mode operasi 1 pensaklaran $\mathrm{H}_{1}$ - $\mathrm{L}_{2}$ Fasa A - B

Pada Gambar 5 mode operasi 1 dijelaskan saklar $\mathrm{H}_{1}$ dan $\mathrm{L}_{2}$ beroperasi ON-OFF secara bergantian dengan frekuensi tinggi, sehingga arus mengalir dari fasa A ke fasa $B$.

\section{B. Mode Operasi 2 : $\mathrm{H}_{3}$ dan $\mathrm{L}_{2} \mathrm{ON}$}

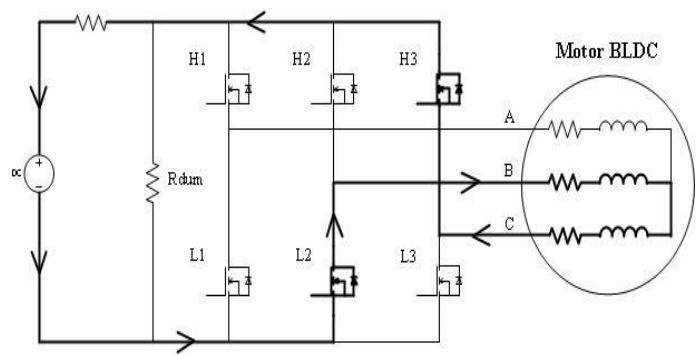

Gambar 6 mode operasi 2 pensaklaran $\mathrm{H}_{3}-\mathrm{L}_{2}$ Fasa C - B

Gambar 6 hasil mode operasi 2 saklar $\mathrm{H}_{3}$ dan $\mathrm{L}_{2}$ beroperasi ON-OFF secara bergantian dengan frekuensi tinggi, sehingga arus mengalir dari fasa C ke fasa $B$.

\section{Mode Operasi $3: \mathrm{H}_{3}$ dan $\mathrm{L}_{1} \mathrm{ON}$}

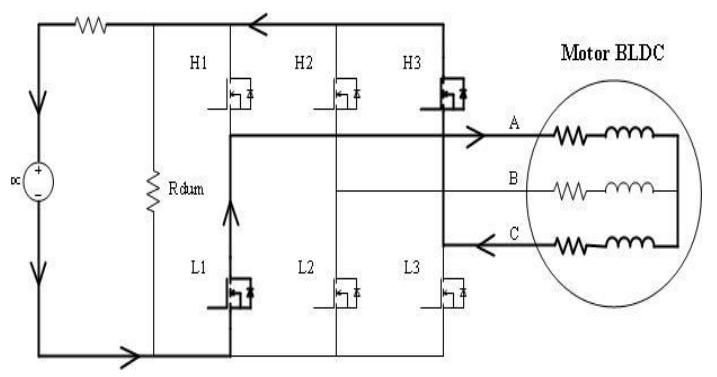

Gambar 7 mode operasi 3 pensaklaran $\mathrm{H}_{3}-\mathrm{L}_{1}$ Fasa $\mathrm{C}$ - $\mathrm{A}$

Mode operasi 3 ditunjukkan pada Gambar 7, saklar $\mathrm{H}_{3}$ dan $\mathrm{L}_{1}$ beroperasi ON-OFF secara bergantian dengan frekuensi tinggi, sehingga arus mengalir dari fasa $\mathrm{C}$ ke fasa $\mathrm{A}$.

\section{Mode Operasi 4 : $\mathrm{H}_{2}$ dan $\mathrm{L}_{1} \mathrm{ON}$}

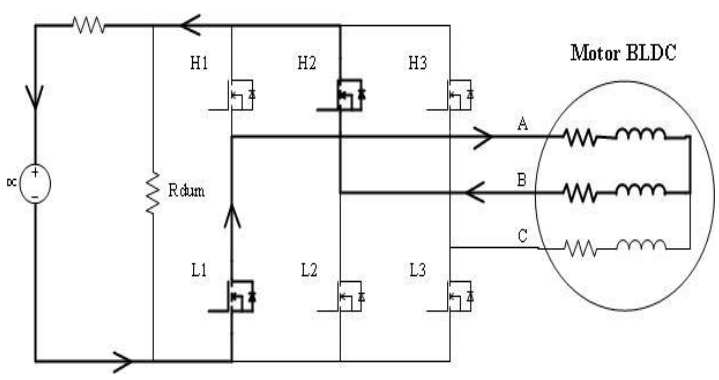

Gambar 8 mode operasi 4 pensaklaran $\mathrm{H}_{2}$ - $\mathrm{L}_{1}$ Fasa B - A

Pada Gambar 8 mode operasi 4 dijelaskan saklar $\mathrm{H}_{2}$ dan $\mathrm{L}_{1}$ beroperasi ON-OFF secara bergantian dengan frekuensi tinggi, sehingga arus mengalir dari fasa B ke fasa A.

\section{E. Mode Operasi 5 : $\mathrm{H}_{2}$ dan $\mathrm{L}_{3} \mathrm{ON}$}

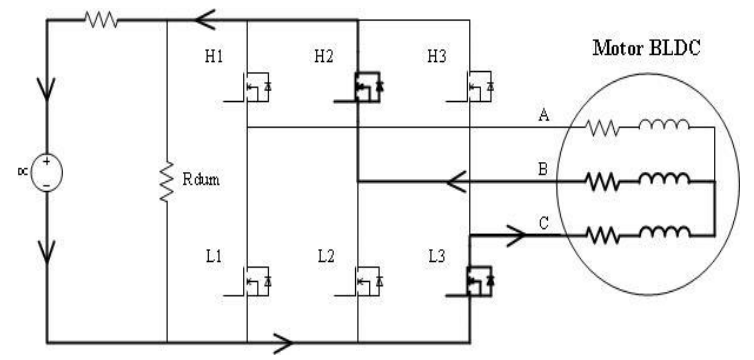

Gambar 9 mode operasi 5 pensaklaran $\mathrm{H}_{2}$ - $\mathrm{L}_{3}$ Fasa B - C

Pada Gambar 9 mode operasi 5 dijelaskan saklar $\mathrm{H}_{2}$ dan $\mathrm{L}_{3}$ beroperasi ON-OFF secara bergantian dengan frekuensi tinggi, sehingga arus mengalir dari fasa $\mathrm{B}$ ke fasa $\mathrm{C}$.

\section{F. Mode Operasi $6: \mathrm{H}_{1}$ dan $\mathrm{L}_{3} \mathrm{ON}$}

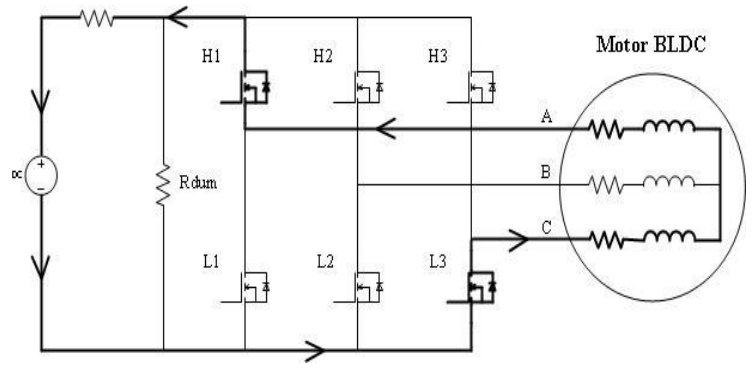

Gambar 10 mode operasi 6 pensaklaran $\mathrm{H}_{1}$ - L $\mathrm{L}_{3}$ Fasa A-C

Pada Gambar 10 mode operasi 6 dijelaskan saklar $\mathrm{H}_{1}$ dan $\mathrm{L}_{3}$ beroperasi ON-OFF secara bergantian dengan frekuensi tinggi, sehingga arus mengalir dari fasa A ke fasa C. Energi lebih yang tersimpan pada belitan motor BLDC akan dipindahkan ke batere saat mode operasi bekerja. 


\section{Hasil dan Pembahasan}

Pada Gambar 11 disajikan hasil simulasi pada saat duty cycle $75 \%$ dengan menggunakan perangkat lunak power simulation (Psim). Dari hasil simulasi dapat dibuktikan bahwa pada saat duty cycle diubah-ubah maka tegangan keluaran mengalami perubahan, yang ditunjukan pada Gambar 12 dan terjadi perubahan energi dengan melihat indikator pada arus yang disimpan ke batere yang dapat dilihat pada Gambar 13.

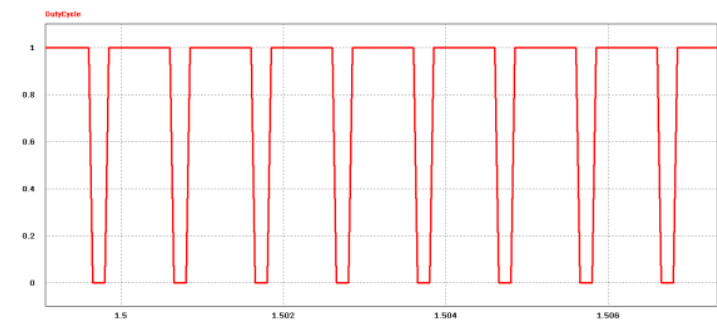

Gambar 11 hasil simulasi gelombang keluaran mikrokontroller pada duty cycle $75 \%$

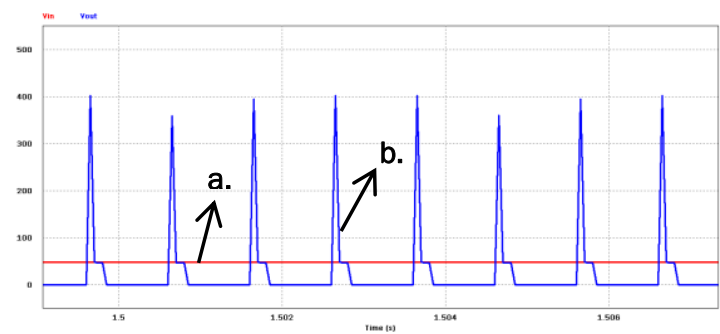

Gambar 12 hasil simulasi tegangan pada duty cycle $75 \%$ a. tegangan masukan batere dan $b$. Tegangan keluaran inverter

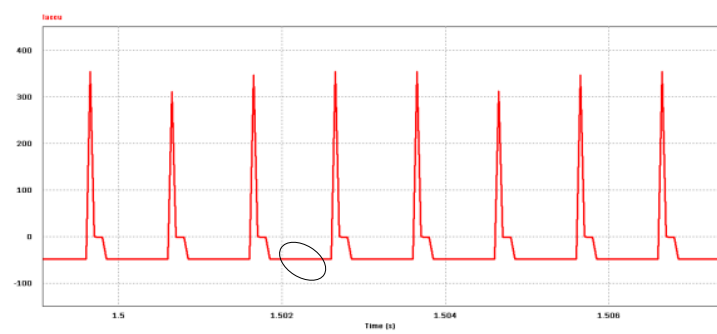

Gambar 13 hasil simulasi keluaran arus yang masuk ke batere pada duty cycle $75 \%$

Untuk pengujian Laboratorium digunakan perangkat yang disajikan pada Gambar 14

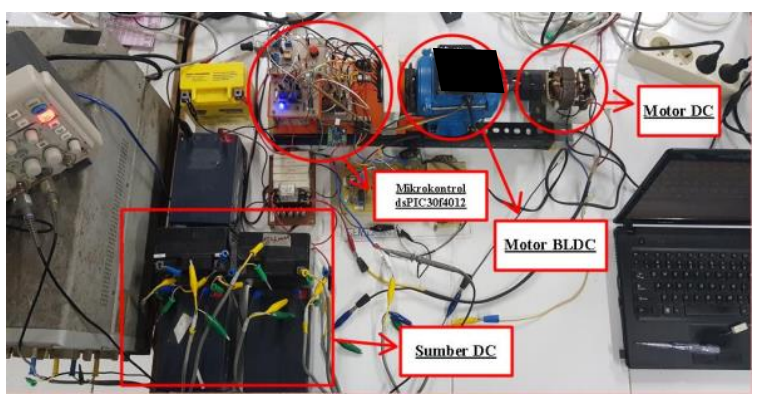

Gambar 14 prototipe konstruksi perangkat keras alat uji
Hasil pengujian pada prototipe memiliki hasil yang hampir sama dengan hasil simulasi. Hasil pengujian alat uji dapat dilihat pada bab selanjutnya.

Pengujian alat saat beroperasi dengan kondisi duty cycle 25\%. Saat kondisi ini, perpindahan energi masih belum tampak. Dapat dilihat pada Gambar 17, arus yang masuk ke baterai masih sedikit sekali dan kecepatan sedikit rendah. Menghasilkan kecepatan maksimal 687.4 rpm.

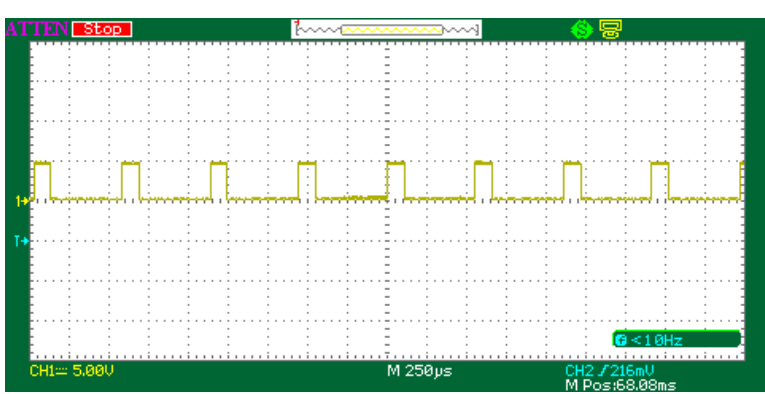

Gambar 15 hasil pengujian gelombong keluaran mikrokontroller pada duty cycle $25 \%$

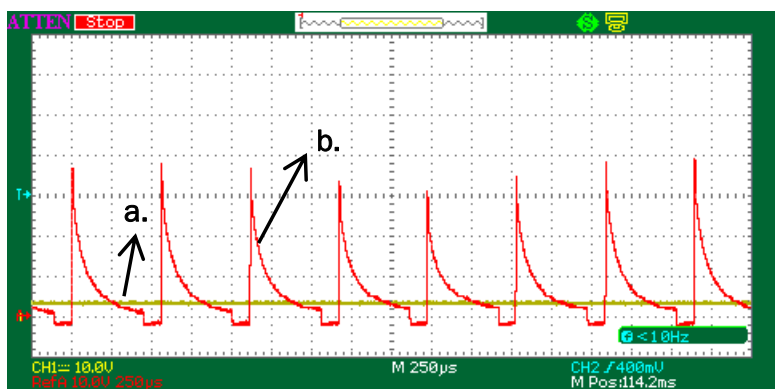

Gambar 16 hasil pengujian tegangan pada duty cycle $25 \%$ a. tegangan masukan batere dan $b$. tegangan keluaran inverter

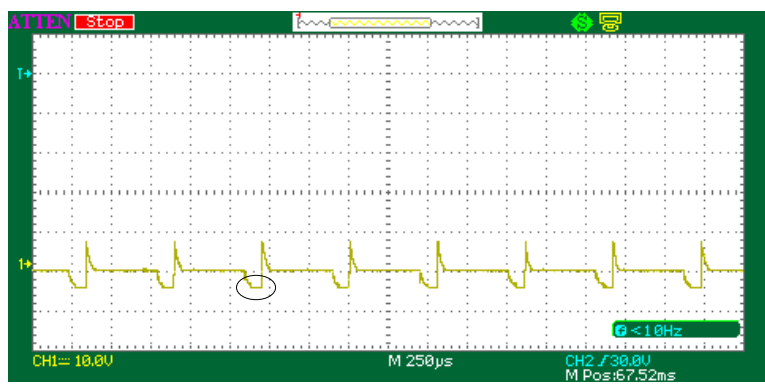

Gambar 17 hasil pengujian keluaran arus yang disimpan batere pada duty cycle $25 \%$

Pengujian selanjutnya dengan menggunakan kondisi duty cycle 50\%. Saat kondisi ini, perpindahan energi mulai sedikit tampak. Dapat dilihat pada Gambar 20, arus yang masuk ke baterai masih sedikit dan kecepatan mulai rendah. Dengan menghasilkan kecepatan maksimal 598.8 rpm. 


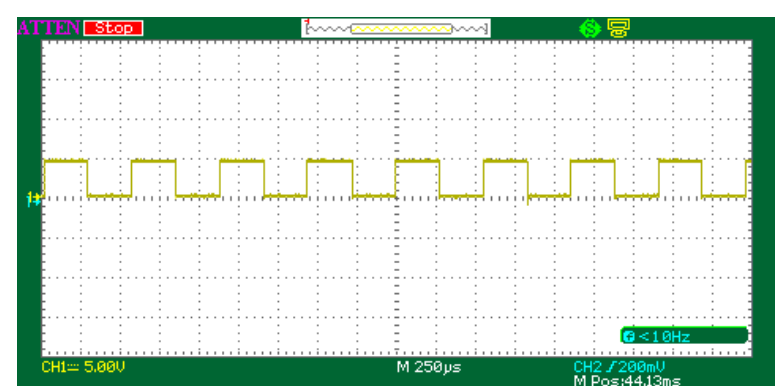

Gambar 18 hasil pengujian gelombong keluaran mikrokontroller pada duty cycle $50 \%$

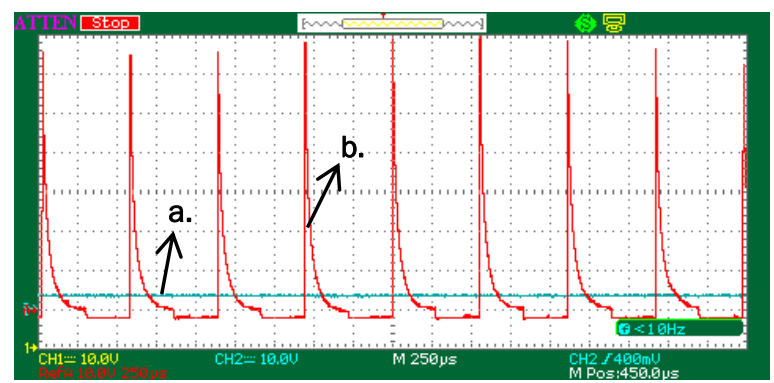

Gambar 19 hasil pengujian tegangan pada duty cycle $50 \%$ a. tegangan masukan batere dan $b$. tegangan keluaran inverter

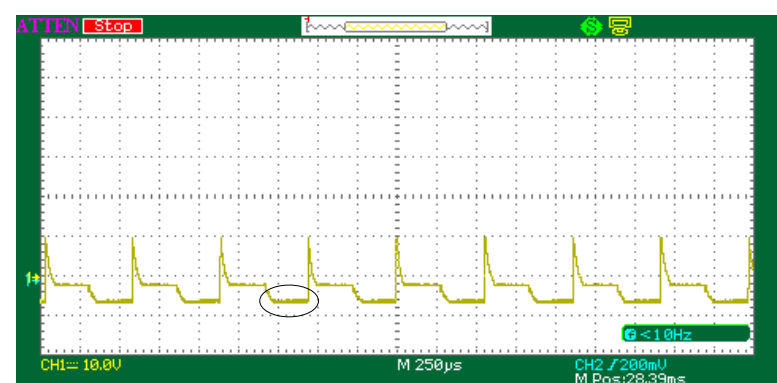

Gambar 20 hasil pengujian keluaran arus yang disimpan batere pada duty cycle $50 \%$

Pengujian terakhir menggunakan kondisi duty cycle $75 \%$. Saat kondisi ini, perpindahan energi sudah mulai tampak. Dapat dilihat pada Gambar 23, arus yang masuk ke baterai sudah bnyak dan kecepatan menjadi rendah sekali. Dengan menghasilkan kecepatan maksimal 486.0 rpm.

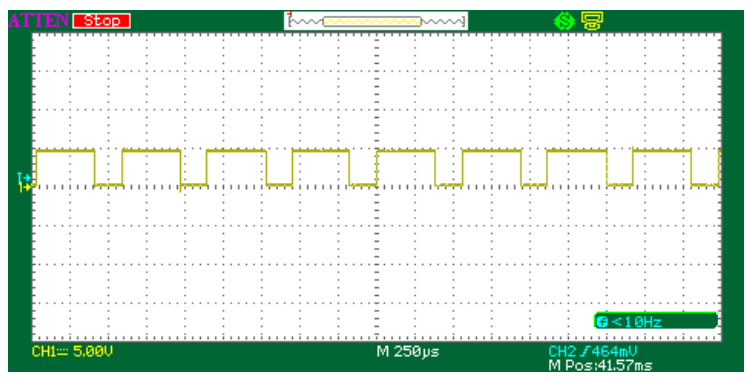

Gambar 21 hasil pengujian gelombong keluaran mikrokontroller pada duty cycle $75 \%$

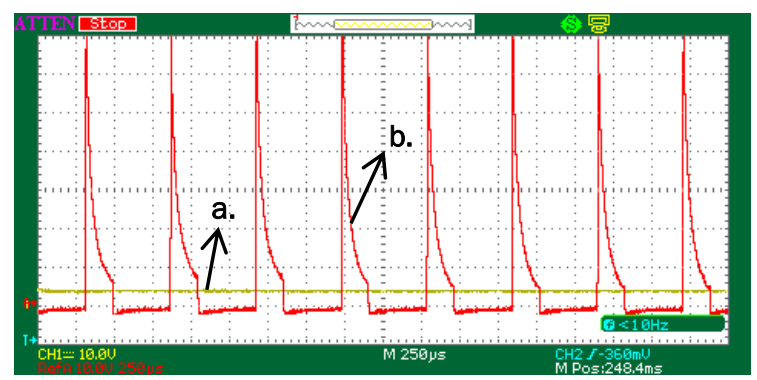

Gambar 22 hasil pengujian tegangan pada duty cycle $75 \%$ a. tegangan masukan batere dan $b$. tegangan keluaran inverter

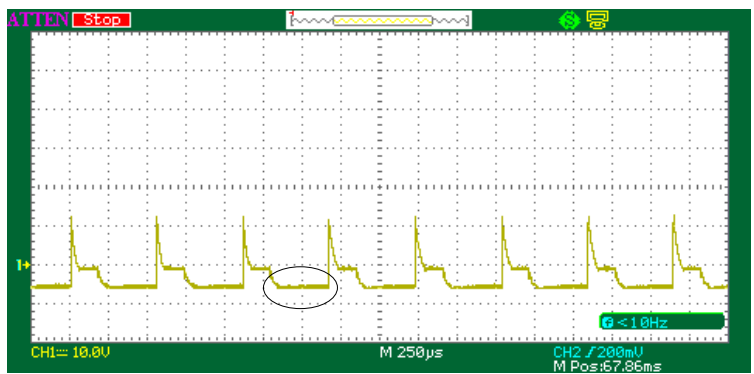

Gambar 23 hasil pengujian keluaran arus yang disimpan batere pada duty cycle $75 \%$

Untuk mengetahui besar persentase duty cycle, arus yang masuk pada batere dan kecepatan motor, hasil pengujian prototipe alat uji dapat disajikan pada Tabel 1 dan Gambar 24.

Table 1 ringkasan hasil pengujian alat

\begin{tabular}{|c|c|c|}
\hline No. & duty cycle & $\begin{array}{c}\text { Kecepatan } \\
\text { (RPM) }\end{array}$ \\
\hline 1. & $25 \%$ & $(687.4)$ \\
\hline 2. & $50 \%$ & $(598.8)$ \\
\hline 3. & $75 \%$ & $(486.0)$ \\
\hline
\end{tabular}

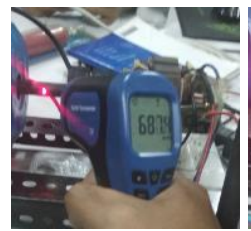

a.

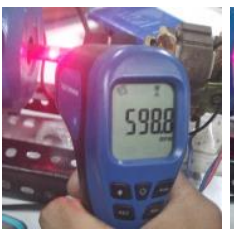

b.

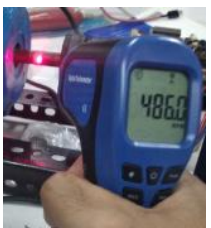

c.
Gambar 24 hasil pengujian kecepatan motor menggunakan tachometer a. duty cycle $25 \%$ b. duty cycle $50 \%$ dan c. duty cycle $75 \%$ 


\section{Kesimpulan}

Saat motor BLDC menjadi mode generator terbukti bahwa tegangan keluaran pada motor BLDC lebih rendah daripada tegangan batere. Karena sebagai syarat untuk pengereman regeneratif, tegangan pada keluaran inverter harus lebih besar dari tegangan batere, maka inverter difungsikan sebagai boost konveter. Apabila duty cycle dibesarkan, maka tegangan keluaran pada inverter akan besar pula dan arus yang masuk ke batere juga besar, sehingga kecepatan pada motor menjadi rendah.

\section{Daftar Pustaka}

[1] Gaurav A. Chandak, A. A. Bhole, “AN ELECTRIC BRAKING SYSTEM CONTROLLER FOR BRUSHLESS DC MOTOR IN ELECTRIC VEHICLE APPLICATION", International Journal of Electrical Engineering \& Technology (IJEET) Vol. 8, pp. 48-56, Issue 4, July-August 2017.

[2] Xu Jiaqun, Cui Haotian, "Regenerative Brake of Brushless DC Motor for Light Electric Vehicle" unpublished", ICEMS, Thailand, October 2015.

[3] Tejo Sukmadi, Syauqie Candra Buana, Trias Andromeda, and Mochammad Facta, "A Prototype of Multistage Dynamic Braking of Three Phase Squirrel Cage Induction Motor" Int. Conf. on Information Tech., Computer, and Electrical Engineering (ICITACEE), Indonesia, Oct 19-21st 2016.

[4] Mingli Shang, Liang Chu, Jianhua Guo, Yong Fang, and Feikun Zhou, "Braking Force Dynamic Coordinated Control for Hybrid Electric Vehicles", IEEE, 2010.

[5] V. Vijaya Kumar, V. Udayakumar, and J. M. Uruganandham, "SPEED CONTROL OF BLDC MOTOR FOR FOUR QUADRANT OPERATION WITHOUT LOSS OF POWER" INTERNATIONAL CONFERENCE ON COMPUTATION OF POWER,

\section{Nomenklatur}

Daftar nomenklatur

$R$

L

$\mathrm{K} v$

$\mathrm{K} \tau$

BEMF

RPM

Ton

Toff

ENERGY,

$$
=\text { Hambatan }
$$$$
=\text { Induktor }
$$$$
\text { = Tegangan Konstan Motor }
$$$$
\text { = Konstan Torsi }
$$

= Back Electromotive Force

$=$ Rotasi Per Menit

= Periode Waktu ON

= Periode Waktu OFF

COMMUNICATION, 2015.

[6] Microchip, Application Note 957, "Sensored BLDC Motor Control Using dsPIC30F2010", Microchip Technology Inc, 2004.

[7] Ye Tao, Xiaohua Xie, Haiyan Zhao, Wei Xu, Hong Chen, "A Regenerative Braking System for Electric Vehicle with Four In-wheel Motors Based on Fuzzy Control", IEEE Proceedings of the 36th Chinese Control Conference, China, July 26-28, 2017.

[8] M.K Yoong, Y.H Gan, G.D Gan, C.K Leong, Z.Y Phuan, B.K Cheah. K.W Chew, "Studies of Regenerative Braking in Electric Vehicl", IEEE Conference on Sustainable Utilization and Development in Engineering and Technology, Malaysia, 20 \& 21 November, 2010.

[9] Xiaohong Nian, Fei Peng, and Hang Zhang, "Regenerative Braking System of Electric Vehicle Driven by Brushless DC Motor", IEEE TRANSACTIONS ON INDUSTRIAL ELECTRONICS, VOL. 61, NO. 10, OCTOBER 2014.

[10]Microchip, Application Note 857, "Brushless DC Motor Control Made Easy", Microchip Technology Inc, 2011. 